\title{
William Wyler's 1939 Adaptation of Wuthering Heights: An Attempt to Restore the Idea of America Dream
}

\author{
Muhammad Hussein Oroskhan \\ Department of English Literature, Faculty of Foreign Languages, Shiraz University, Shiraz, Fars, Iran
}

\begin{abstract}
The competition between word and image to take a priority over each other as the better medium reached a turning point by the advent of cinema in twentieth century. The resonance of competition soon faded away when critics began to study not the extent to which one film adaptation is imitating the literary work but the discursive field behind each cinematic adaptation. In this respect, the great status of each literary adaptation is readily justified. Under this purview, the mainstay of literary adaptations is controlled within a certain discursive practice. As such, the principle that pervades Hollywood literary production is tinged with the idea of American dream as the predominant discursive formation running through the whole system. Nevertheless, at the critical moment of Great depression, the necessity of encapsulating the idea of American dream was stressed more than ever since America needed to rebuild the shattered idea on which the country has been built itself. Therefore, the contribution of this paper lies in studying William Wyler's 1939 Adaptation of Wuthering Heights with respect to Michel Foucault's theory of discourse to prove that this literary adaptation is produced with the purpose of advertising the idea of American dream shattered during the Great depression.
\end{abstract}

Index Terms-American dream, discursive formation, Wuthering Heights

\section{INTRODUCTION}

Novels anchor an overall trajectory throughout nineteenth century, providing a succession of lenses for the people to see the life in various perspectives. Proclaiming the major force of nineteenth century, novelists were making earnest endeavor to beat their long-standing rivals/painters, no wonder that Charles Dickens emphasized that "he had 'painted' Oliver Twist" (34) or Thomas Hardy provided the subtitle of "A Rural Painting in the Dutch School" for his novel Under the Greenwood Tree (Elliot, 2004, p. 8). Their competition labeled by Kamilla Elliott as "Word/Image Wars" has been an ongoing competition ever since except that in twentieth century it took a new form of rivalry by the advent of cinema, a new way of pictorial presentation. As novelists, who were writing in a then-new medium in literature in eighteenth and nineteenth, tried to emulate the long-standing medium of arts like painting by recounting its visual beauty in words, cinema at the beginning of its tradition tallied with the same perspective, trying to put literary works on the screen. This can explain why "according to 1992 statistics, 85 percent of all Oscar-winning Best Pictures are adaptations" (Hucheon, 2014, p. 4).

With regard to the recent conflict between cinema and literature, Linda Hutcheon in his monumental work entitled $A$ Theory of Adaptation has marked all the hostile words like '"betrayal,' 'deformation,' 'perversion,' 'infidelity,' and 'desecration'" which are used to attack cinematic adaptation of literary works as unfair remarks since in this process "there is inevitably a certain amount of re-accentuation and refocusing of themes, characters, and plot" (p. 40) which consequently makes a literary adaptation not a mere imitation of a literary work but a new work in its own status. Moreover, for Hutcheon, the decisive factor fostering this development is the context through which the adaptation is taking place; "context can modify meaning, no matter where or when" (p. 147). The important role of context can be further extended to have an "intertextual engagement with the adapted work" (p. 9). As such, the film adaptation is never necessarily a mere copy of the original text but a reworking with respect to the new context. In a similar perspective, Francesco Casetti (2004) believes in the reappearance of the original text in "another discursive field, of an element (a plot, a theme, a character, etc) that has previously appeared elsewhere" (p. 83). He asserts that an adapted work should develop "a new communicative situation" (p. 83), through which a new work is prepared for the targeted audience. In fact, his view is merely in line with Michel Foucault's definition of discourse as a "system which structures the way that we perceive reality" $(1972$, p. 55). With the same perspective, we try to address the film adaptation of Wuthering Heights produced in 1939 by William Wyler with the same methodological approach, proving that the this special film production is actually the representation of American dream after the harsh time of the Great Depression so as to change the world's view toward American, a view that has been shattered by the difficult time of Great Depression.

\section{AMERICAN DREAM AS THE DisCURSIVE Formation OF AMERICAN SOCIETY}


The United States was never founded by a single group of people or even by a group of people attributed with one feature at least. Many people from different social, political and racial background came to this land for the purpose of better life. The country was not a coherent society by its commencement date and it was more like "a colonial America as a 'fragment' society" (Jillson, 2016, p. 2). Clearly, it always revolved around the exigencies of shaping a common platform to decrease all these ethic, cultural, linguistic and political background and unify all the people for a common purpose. Interestingly, the platform could not be attached to anything specific and should be all fluid flowing with different people. As such, this country began its journey with an idea; "from the times of Columbus, Cortez, and John Smith, America has been an idea, or many ideas" (p. 150). This idea that can be easily noticed in everybody's words from Barak Obama to Bill Clinton (p. 1) or even a poor immigrant coming to the United States is called "American Dream", a highly distinctive phrase heard anywhere; one is talking of America.

The root of this now-prevalent idea lies in 1780 when Benjamin Franklin began to put into words his style of living for the guidance of other people. From that moment on, "the pages of Poor Richard's Almanac, had been defining the core of the dream for decades: prepare, work, save, invest, catch a break, and success will be yours" (Olney, 1980, p. 50). Benjamin's writing was a real comfort for the immigrant coming to America as it clearly encompassed the notion that "though many arrive in America as poor 'servants or Journeymen, . . . if they are sober, industrious, and frugal, they soon become Masters, establish themselves in Business, marry, raise families, and become respectable Citizens" (Jillson, 2016, p. 4). Indeed, the American dream became the decisive factor to distinguish America from any other country around the world as Scott Fitzgerald mentioned that "America is not a land or a people: France was a land, England was a people, but America, having about it still that quality of the idea" (1956, p. 97). The other point about the American dream is that it is so embedded in American's lives that it includes "images both of the nation within the world and of the individual within the nation"(Jillson, 2016, p. 17). To better understand the key role of American dream in the expression of America to the world and the individual living in America, it is vital to refer to Michel Foucault's theory of discourse.

Michel Foucault (1926-1984) is still one of the important figures in critical theories specifically with regard to the concept of "power, knowledge and discourse" (Balls et al., 2010, p. 1). He extended the notion of discourse in his The Archaeology of Knowledge (1972). He simply defines the concept of discourse as "a group of statements in so far as they belong to the same discursive formation" (Foucault, p. 117). With regard to this simple definition, one should further try to grasp two critical terms of statement and discursive formation embedded here to get a hold of the concept of the discourse. Foucault's statement "defines the conditions of its specific existence" (p. 31), which is an offshoot of discursive formation. In fact, his critical term is discursive formation since in his view "there is no non-discursive realm" (p. 55). With respect to discursive realm, he further contends that discursive practices are "the delimitation of a field of objects, the definition of a legitimate perspective for the agent of knowledge and the fixing of norms for the elaboration of concepts and theories" (p. 57). Affirming Foucault's definition of these two critical terms, it seems that the process leading to the "formation of the occurrence of statements in a particular time at a particular place" (p. 140) is of prime importance. Clearly, Foucault's purpose is not to solely determine the existence of each discourse but more to clarify the "rules for discursive practices that run through individual oeuvres, sometimes govern them entirely, and dominates them to such an extent that nothing eludes them" (ibid.).

Foucault's view marks a watershed in the establishment of a relation between the society and the individual by disclosing the role of each prevalent discourse manipulating the constitution of reality and thoughts within different individuals in each society, in other word, anything produced in the society is "controlled, selected, organized and redistributed by a certain number of procedures whose role is to ward off its powers and dangers, to gain mastery over its chance events, to evade its ponderous, formidable materiality" (p. 52). In this respect, the production of reality is synonymous with the discourse resulted from the specific discursive formation in that society. This being the case, American dream as a predominant discourse has dominated and pervaded the American life and surely the debate over the definition and the role of American dream was never limited to a specific time; it was persistently controlling the American life from its beginning in 1780s. Throughout all these years, American dream has cast its net much more widely, encompassing all the social reality, nevertheless, at a specific juncture in America's history, a crying need for the ideals of American dream to reconstruct the lost social reality for American people was felt more than ever and it was during the Great Depression spanning through the America from 1929 to 1939. Lionel Trilling (1930) remarks that "Americans were losing a sense of self and being reduced to something less than full and complete human beings" (Hauhart, 2016, p. 72). In this regard" ,the American Dream, conceived as a spur to achievement, produced instead a tendency during the Depression for men to seek cover from the economic downturn" (ibid). Though American dream has always been there as an idea or the source of discursive formation spreading its statements for the construction of reality in American, during the Great Depression, any institution was recruited to encapsulate the very essence of American dream. Of all the institution, Hollywood, the American biggest film industry, most earnestly took on this mantle of recovering Americans' self-confidence through American dream by its promotion on the screen.

\section{The Role of American Dream as the Discursive Formation in 1939 Adaptation of WutherinG HEIGHTS}

Among the classic Hollywood production of British literature, the film production that most minutely follows this path of constructing the American Dreams anew is 1939 production of Wuthering Heights. Ever since eight specific 
adaptations have been produced in 1939, 1970, 1978, 1992, 1998, 2003, 2009 and 2011 if not considering the 1920 silent film production of Wuthering Heights which has been damaged and is not available anymore. The significance of choosing 1939 production is its importance in fixing the image of novel in everybody's mind to the extent that "it has greatly influenced later film adaptation of Wuthering Heights, many of which draw primarily from Wyler's adaptations of the novel more than from the novel itself" (Shachar, 2009, p. 29). The corpus of academic works developing the reason behind the 1939 filmic production has mainly relate film adaptation to attract "a mass audience rather than an elite one with the result being the reworking of the narrative as an appealing love story that is conveyed through beautiful imagery" (Ingham, 2006, p. 228) or as Hila Sachar extending Ingham's argument claims that "the entire film seems to be consumed by an almost overt consciousness of visual display and spectacle" (2009, p. 57). Nevertheless, none of these works have observed the importance of the predominant American discourse in shaping the film production at a time when America is eventually releasing itself from the Great Depression.

The significant difference between the film production and the novel lies in the moment that Heathcliff is back to Wuthering Heights after three years while Lockwood and Nelly are discussing the source of this change by guessing and providing different possible sources as the main reason on this drastic change. In this respect, Nelly replies Lockwood back in this way:

Lockwood: Did he finish his education on the Continent, and come back a gentleman? or did he get a sizar's place at college, or escape to America, and earn honours by drawing blood from his foster-country? or make a fortune more promptly on the English highways?'

Nelly: He may have done a little in all these vocations, Mr. Lockwood; but I couldn't give my word for any. I stated before that I didn't know how he gained his money; neither am I aware of the means he took to raise his mind from the savage ignorance into which it was sunk. (Bronte, 2003, 116)

Nevertheless, this ambiguity is never followed in the film production and is totally avoided by making America as the source of civilizing Heathcliff and making him an honorable person when Edgar is talking to Catherine;

Catherine: Where has he been?

Nelly: America, he said. He's so changed, I hardly recognized him.

Catherine: For the better, I hope.

Nelly: Oh, yes. He's quite the gentlemen. Fine clothes, a horse.

Catherine: Go tell him I don't wish to see him.

Edgar: Oh, nonsense, Cathy. We can't be as cruel as that. He's come a long way, and he's a fine gentleman, so Ellen says. Let's see how America's managed to make a silk purse out of Master Heathcliff. (00:50:00)

The pivotal dialogue between Edgar and Catherine can clearly show the drastic change in the film production for a particular purpose. The discursive formation of the time and place more than ever needs to paint an attractive picture of America that has been the land of dreams for many people for centuries but now suffering greatly from the Great Depression. As such, what possible choice better than working on a classical British novel whose source of ambiguity can be of great help for restoring the great picture of America and helps it to be back on stage. In this regard, as the discursive realm of this film adaptation has been determined, all the statements occur within this realm which means that the details of the film follow not the novel but the predominant discursive formation. With this critical notion, Heathcliff as the person who has gone and come back from America is the carrier of the notion of a man promoting the idea of American dream. On the other hand, this man should be worthy of this carriage, therefore, all the detail of the novel portraying Heathcliff as a negative person are changed in a way to picture a person good enough to follow the path of American dream.

At the beginning of the film, presentation of Heathcliff is so much different with the original presentation of Heathcliff in the novel. Heathcliff is presented in the novel as a person who "forms a singular contrast to his abode and style of living. He is a dark skinned gipsy in aspect, in dress and manners a gentleman" (Bronte, 2003, p. 6) whereas the filmic presentation tries to vividly depicts Heathcliff as a white-skinned man when Laurence Olivier is selected to play the role of Heathcliff, a white and handsome man who is already famous for his part on great classical literary adaptations. More obvious, here is the way black people are treated by this idea. Indeed, "the treatment of blacks has been the most glaring deviation from the American Creed" (Jillson, 2016, p. 7). Though this is surely a negative aspect of American dream, its portrayal shows the exact following of this literary adaptation from the discursive formation of the time of America which deemed black people as unsuited to follow the American dream.

Moreover, the construction of Heathcliff character from childhood to adulthood is also changed to match this situation. The first one is the moment when Heathcliff is brought home by Mr. Earnshaw. In the novel, the boy is not only warmly welcomed by Cathy and Hindly but also is seemingly considered as an evil source causing the destruction of their souvenirs from Liverpool since both Hindly's fiddle and Cathy's whip have been ruined because of Mr. Earnshaw's less care of these things and more care of Heathcliff. As a result, Heathcliff is confronted by Catherine's harsh words;

The former was a boy of fourteen, but when he drew out what had been a fiddle, crushed to morsels in the great-coat, he blubbered aloud; and Cathy, when she learned the master had lost her whip in attending on the stranger, showed her humor by grinning and spitting at the stupid little thing. (Bronte, 2003, p. 46) 
On the other hand, the film adaptation shows Mr. Earnshaw delivers the souvenirs in good condition to the children and when Cathy reacts badly toward Heathcliff, she is berated by Mr. Earnshaw:

Mr. Earnshaw: Oh, children. This is a little gentleman I met in Liverpool who will pay us a visit. Catherine: He... He's dirty. Mr. Earnshaw: Oh, no. Don't make me ashamed of you, Cathy. (00:12:40)

This small change in the film adaptation justifies the audience to solely sympathizes with Heathcliff and considers him to be not worthy of this unfair treatment. Another more important part is the moment when Heathcliff is arguing with Hindley over a colt. In the novel, Heathcliff due to being so much close to Mr. Earnshaw has been able to take the better colt, however, his colt has become sick and now he is applying his leverage of Mr. Earnshaw's favor to force Hindley to give him his colt and finally he is able to obtain the possession of the colt:

He (Heathcliff) said to Hindley- You must exchange horses with me: I don't like mine; and if you won't I shall tell your father of the three thrashings you've given me this week, and show him my arm, which is black to the shoulder.'... 'Take my colt, Gipsy, then!' said young Earnshaw. (Bronte, 2003, p. 49)

Yet, this part of the novel is radically reversed in favor of Heathcliff when Hindley is portrayed as the one forcing Heathcliff to give him his colt:

Heathcliff: What do you want?

Hindley: This horse.

Heathcliff: You can't have him. He's mine!

Hindley: Mine's lame. I'm riding yours. Give him to me or I'll tell Father you boasted you'd turn me out when he died!

Heathcliff: That's a lie! I never said such a thing.

Hindley: He didn't! You never had a father! You gypsy beggar! (00:14:10)

These small changes may never seem to be so much influential at the surface, still they should be considered as some statements within the discursive formation of American dream, their significance can be easily revealed to the audience as it is important that those trying to follow the steps of American dream should be virtuous in character; "everyone who steadfastly practices certain practical virtues will find a place at the table. . . These virtues- self-control, discipline, effort, perseverance, and responsibility—stand at the core of our. . idea of good character" (Schwarz, 1997, p. 6). Based upon this reason Heathcliff is never portrayed as an immoral and ruthless person. Even in a metaphorical scene, Heathcliff as a child seems to be born again when he defeats the black knight:

Catherine: Here, take your lance and charge! See that black knight at the drawbridge?

Challenge him! Charge!

Heathcliff: I challenge you to mortal combat, Black Knight!

Catherine: Heathcliff! You've killed him! You've killed the black knight! (00:17:00)

This moment is really revealing since from now on, the audience would see a totally different Heathcliff until his adulthood, even when he marries Isabella, he is still described as a caring husband and Hindley is introduced as the cause of troubled and uneasy relationship between Heathcliff and Isabella:

Isabella: Why do we have him here? I can't breathe with him in the house.

Heathcliff: Existence would be so much less without my boyhood friend under my roof. Don't you see?

Isabella: You poison yourself with hating him. Darling, please send him away and let love come into the house. (01:27:00)

This source never exists in the novel as Hindley has died previously and Heathcliff for the sake of seeking revenge from the Earnshaw's' is badly treating Isabella. This harsh and unfair treatment is revealed through Isabell's corresponding with Nelly; "Ellen, with your old master's habits. He is clearly on the verge of madness: he was so last night at least. I shuddered to be near him, and thought on the servant's ill-bred moroseness as comparatively agreeable" (Bronte, 2003, p. 188). The other main difference between the novel and the film adaptation is through the portrayal of the character of Catherine which is in exact following of the discursive formation of American dream and in almost the opposite respect of the novel. Through the novel Catherine is depicted to be whimsy, each time trying to get his chance with anybody she likes without any regard for her commitment to someone else. At first, Catherine is in love with Heathcliff but suddenly changes her perspective due to her acquaintance with Edgar and begins to love him:

Nelly: Why do you love him, Miss Cathy?

Catherine: Nonsense, I do that's sufficient.

Nelly: By no means; you must say why?

Catherine: Well, because he is handsome, and pleasant to be with.

Nelly: Bad! was my commentary.

Catherine: And because he is young and cheerful.

Nelly: Bad, still.

Catherine: And because he loves me.

Nelly: Indifferent, coming there.

Catherine: And he will be rich, and I shall like to be the greatest woman of the neighbourhood, and I shall be proud of having such a husband. (Bronte, 2003, p. 99) 
But when Catherine is married to Mr. Linton and Heathcliff is back in a totally changed appearance and behavior, Catherine is highly tended toward him, neglecting her commitment to her husband so much as her husband is forced to ask Catherine to choose between him and Heathcliff:

'"To get rid of me, answer my question,' persevered Mr. Linton. 'You must answer it; and that violence does not alarm me. I have found that you can be as stoical as anyone, when you please. Will you give up Heathcliff hereafter, or will you give up me?" (p. 151)

But through the film adaptation, Catherine is a very submissive girl, each time she is with any of them, Edgar or Heathcliff; she is only obeying them regardless of her love toward the other one, just abiding by her role as a wife. In the beginning when she is with Heathcliff, she even denigrates herself to the status of slave for Heathcliff; "Catherine: but I'm still your slave/Heathcliff: No, Cathy. I now make you my queen. Whatever happens out there, here you will always be my queen" (00:17:00). This status is totally changed when Heathcliff is absent and Catherine marries Edgar. In a scene that Heathcliff visits Catherine and Edgar, he is confronted by a blunt reaction from Catherine when she says:

Edgar and I have many neighbors whom we receive with hospitality and friendship. If you are to be one of them, you're welcome to visit our house... but not with a scowl on your face or an old bitterness in your heart. (01:01:09)

When America was founded on the idea of American dream, unfortunately only certain types of people were suited enough to follow the path of American dream and to finally achieve prosperity and make an ideal country, in other word, "virtually all women, and many poor and dependent white men were outside the 'imagined community' of American citizens at the founding" (Jillson, 2016, p. 60). Though through the twentieth century, there have been many attempts by women to struggle for their rights but still at the time of this production, they haven't been fully able to separate themselves from their roots which defined their status as "wives to love, honor, and obey their husbands" (p. 7). In the same line, this filmic production is following this status of women and situating Catherine as a wife solely at the service of his husband who is the fitted one to pursue the path of American dream effectively. Besides, the literary adaptation never covers the whole novel since in the second part of the novel Heathcliff is depicted as carrying the features of a maniac treating children brutally, nevertheless, Heathcliff is supposed to be a virtuous person, as such this part has been justifiably omitted from being shown on the screen.

\section{CONCLUSION}

During the timeline of history, certain things always repeat itself. Once novelists were trying to imitate painters in their writing and once in the twentieth century cinema took the turn of adapting the novels. Beside the conflict, nowadays a literary adaptation is mostly considered as an autonomous work since it is being produced within a new context. The reappearance of the work within a new context is mainly caused by a predominant discourse which is itself an offshoot of discursive formation. As such, America as a society embarked on the idea of American dream can be minutely studied with regard to this view. American's institutions have always been active promoting and shaping the reality of the society out of this American dream. Undoubtedly, the role of Hollywood in shaping such reality is undeniable especially when it is more needed than ever. Hollywood tried to work as a savior salvaging the American dream out of the Great depression through its filmic production. 1939 production of Wuthering Heights is deemed to be an exact instance portraying its main character, Heathcliff, as the kind of man best suited to follow the American dream to achieve prosperity. Through the predominant discourse of American dream, all the details of the novel are changed in accordance with the principles of the American dream and finally the image of a great land on which each person can through handworks and virtuous character achieve whatever he desires is once again restored.

\section{REFERENCES}

[1] Ball, S. J., Gane, M., Rajchman, J., \& Smart, B. (2010). Michel Foucault. Routledge.

[2] Brontë, E., \& Peterson, L. H. (2003). Wuthering Heights. Boston: Bedford/St. Martins.

[3] Casetti, F. (n.d.). (2004). Adaptation and Mis-adaptations. A Companion to Literature and Film, 81-91. doi:10.1002/9780470999127.ch6.

[4] Elliott, K. (n.d.). (2004). Novels, Films, and the Word/Image Wars. A Companion to Literature and Film, 1-22. doi:10.1002/9780470999127.ch1.

[5] Fitzgerald, F. S. (1956). The Crack-Up, ed. Edmund Wilson (New York), p. 197.

[6] Foucault, M. (1972). The Archaeology of Knowledge: Michel Foucault. London: Tavistock Publications.

[7] Hauhart, R. C. (2016). Seeking the American Dream: A Sociological Inquiry. New York: Palgrave Macmillan.

[8] Hutcheon, L. (2014). Theory of Adaptation. London: Taylor and Francis.

[9] Ingham, P. (2006). Brontës (Oxford worlds classics. Authors in context). London: Oxford University Press.

[10] Jillson, C. C. (2016). The American dream: In History, Politics, and Fiction. United States: University Press of Kansas.

[11] Olney, J. (n.d.). (1980) Some Versions of Memory/Some Versions of Bios: The Ontology of Autobiography. Autobiography. doi:10.1515/9781400856312.236.

[12] Sayre, R. F. (n.d.). Autobiography and the Making of America. Autobiography. doi:10.1515/9781400856312.146.

[13] Schwarz, John E. (1997). Illusions of Opportunity: The American Dream in Question. New York: W. W. Norton.

[14] Shachar, Hila. (2009). Wuthering Heights: Screen Adaptations and Cultural Afterlives. London: Palgrave Macmillan.

[15] Wyler, W. (Director). (n.d.). Wuthering Heights [Video file]. 
Muhammad Hussein Oroskhan is currently a PhD candidate at Shiraz University. He has already published a couple of articles in Persian Literature. His main field of interest includes Comparative literature and film studies. He is a lecturer at Yazd University. 